\title{
Interleukin 1- $\beta$, interleukin-1 receptor antagonist and vitamin $D$ levels in children with atopic dermatitis
}

\author{
EDYTA MACHURA ${ }^{1}$, MARIA SZCZEPAŃSKA ${ }^{l}$, BOGDAN MAZUR², KATARZYNA ZIORA ${ }^{l}$, \\ ALICJA KASPERSKA-ZAJĄC ${ }^{3}$
}

${ }^{1}$ Chair and Department of Pediatrics, School of Medicine with the Division of Dentistry in Zabrze, Medical University of Silesia, Katowice, Poland

${ }^{2}$ Chair and Department of Microbiology and Immunology, School of Medicine with the Division of Dentistry in Zabrze, Medical University of Silesia, Katowice, Poland

${ }^{3}$ Clinical Department of Internal Diseases, Dermatology and Allergology, School of Medicine with the Division of Dentistry in Zabrze, Medical University of Silesia, Katowice, Poland

\begin{abstract}
Introduction: Among the broad spectrum of cytokines, interleukin 1- $\beta(I L-1 \beta)$ has been implicated in induction and subsequent aggravation of skin lesions in atopic dermatitis (AD). A considerable body of evidence suggests that vitamin D status also influences the risk and/or severity of $A D$.

Material and methods: Fifty-seven children suffering from mild to severe AD were enrolled in the study. The control group consisted of 33 matched healthy children. In all the children serum concentrations of $I L-1 \beta / I L-1 F 2$ and the interleukin-1 receptor antagonist IL-Ra/lF3 were measured. Serum $25(\mathrm{OH}) D$ concentration was obtained for 49 patients with $A D$ and all healthy children.

Results: In children with AD 59.2\% of children had insufficiency, $24.5 \%$ had deficiency and $16.3 \%$ had a sufficient serum $25(\mathrm{OH}) \mathrm{D}$ level. In the control group 26.5\%, $52.9 \%$ and $20 \%$ of participants had insufficiency/deficiency/sufficiency of $25(\mathrm{OH}) \mathrm{D}$, respectively. The severity of $A D$ was positively correlated with total IgE level, percentage and absolute count of eosinophils and IL-1Ra.IL-1 $\beta$ correlated with IL-1Ra.

Conclusions: In children with $A D$ the serum vitamin D level was lower than in healthy children. The correlation between severity of $A D$ and IL-1Ra may prove that inflammasome-dependent IL-1 $\beta$ is involved in immunopathogenesis of the disease. Further studies are needed on a larger population of children to confirm the role of this cytokine in development of $A D$.
\end{abstract}

Key words: children, atopic dermatitis, vitamin D, interleukin 1- $\beta, I L-1 R a$.

(Centr Eur Immunol 2018; 43 (2): 180-185)

\section{Introduction}

Atopic dermatitis (AD) is the most common inflammatory skin disorder, affecting up to $15-25 \%$ of children [1]. In the final outcome $\mathrm{AD}$ is the consequence of skin barrier dysfunction and immune system disturbances due to the harmful influence of a mixture of genetic and environmental factors. Immunological dysregulation observed in patients with $\mathrm{AD}$ is the result of various defects in the innate and adaptive immune, system causing an inadequate response to environmental antigens. Additionally, environmental pathogens and allergens can stimulate the secretion of numerous cytokines, chemokines and growth factors by the epidermal keratinocytes, which contribute to the skin lesions $[2,3]$.
It has been described in recent literature that among the broad spectrum of cytokines, interleukin 1- $\beta$ (IL-1 $\beta$ ) has been involved in induction and subsequent aggravation of skin lesions in $\mathrm{AD}[4,5]$.

IL- $1 \beta$ is an important representative of the IL- 1 family, members of which play a central role in the innate immune response, and require the intracellular cysteine protease-caspase- 1 for biological activity. Caspase- 1 activation is mediated by a cytosolic multiprotein oligomer, called the inflammasome. Stimulation of the inflammasome is triggered not only by a microbial infection, but also could be the sequela of noninfectious excitation both of exogenous and endogenous origin $[6,7]$. In man the dysregulation of inflammasome activity is associated with nu-

Correspondence: Edyta Machura, MD, PhD, Chair and Department of Pediatrics School of Medicine with the Division of Dentistry in Zabrze, Medical University of Silesia, 13/15 3 Maja St., 41-800 Zabrze, Poland, e-mail: machura@poczta.fm Submitted: 3.10.2016; Accepted: 16.01.2017 
merous proinflammatory, non-microbial diseases. IL-1 $\beta$ is the pivotal cytokine in autoinflammatory diseases such as cryopyrin-associated periodic syndromes (CAPS) [3, 8]. Recent findings also suggest that inflammasome-dependent cytokines are involved in allergic diseases such as asthma, atopic and contact dermatitis and some forms of urticaria [4, 5, 9-11].

Although the role of vitamin D in allergy is still under debate, a considerable body of evidence suggests that vitamin D status influences the risk or severity of AD [12, 13]. The exact mechanism of how the vitamin status is related to the development of AD remains unclear. Vitamin $\mathrm{D}$ is a key regulator of calcium metabolism and has been implicated in normal skin physiology, affecting different aspects of both innate and adaptive immunity. Vitamin D stimulates filaggrin - the protein necessary for stratum corneum barrier formation and enhanced production of antimicrobial peptides. Its anti-inflammatory activity is, at least in part, mediated through regulating cytokine and growth factor expression in various cells of the immune system $[14,15]$.

The aim of our study was to analyze serum levels of IL-1 $\beta$ and its competitive antagonist, IL- 1Ra, as well as the serum 25-hydroxyvitamin D [25(OH)D] concentration in children with AD.

\section{Material and methods}

Fifty-seven children (median age 7, interquartile range [IQR ] 4-11.2 years) suffering from mild to severe AD were enrolled in the study. AD was diagnosed according to the criteria described by Hanifin and Rajka [16]. The severity of dermatitis was estimated according to the SCORAD index, ranging from 0 to 103 points (median value 30, IQR 22-36.5 points) [17]. The patients were not treated with any antihistamines, topical steroids or calcineurin inhibitors for at least 1 week before enrolment in the study (only emollients were applied). They were free of any systemic glucocorticoids during the preceding 8 weeks.
The control group consisted of 34 healthy children (median age 8, IQR 5-14 years) with a negative history of allergic diseases, a normal level of total serum $\mathrm{IgE}$ and negative results of the skin prick test for a panel of aeroallergens (dust mite, mixed grass or tree pollen, cat and dog; Allergopharma, Reinbek, Germany). Children included in the control group attended the outpatient pediatric clinic for non-immunological, non-inflammatory health problems and needed blood tests. The characteristics of the study groups are summarized in Table 1.

The present study was approved by the Ethics Committee of the Medical University of Silesia in Katowice and written informed consent was obtained from children's parents.

The serum concentrations of IL- $1 \beta / \mathrm{IL}-1 \mathrm{~F} 2$ and interleukin-1 receptor antagonist IL-Ra/1F3 were measured with an enzyme-linked immunosorbent assay (ELISA) using Quantikine kits (R\&D Systems, Minneapolis, USA) according to the manufacturer's recommendations. Peripheral venous blood was collected into $5-\mathrm{ml}$ citrate collection tubes. The collected samples were then centrifuged for 15 minutes at $1000 \mathrm{~g}$. The serum samples were divided into aliquots and stored at $-80^{\circ} \mathrm{C}$ until assayed. Repeated freeze-thaw cycles were absolutely avoided for all serum samples. The lower limits for IL-1 $\beta$ and IL-1Ra were $1 \mathrm{pg} / \mathrm{ml}$ and $18.3 \mathrm{pg} / \mathrm{ml}$, respectively.

Serum 25(OH)D concentration obtained for 49 AD patients and all healthy children was measured using an automated direct electrochemiluminescence immunoassay (Elecsys, Roche Diagnostic, Mannheim, Germany) with the detection limit of $3 \mathrm{ng} / \mathrm{ml}$. Sufficient vitamin D concentration was defined as $\geq 30 \mathrm{ng} / \mathrm{ml}$, whereas insufficiency/ deficiency was defined as 20-30 ng/ml and $<20 \mathrm{ng} / \mathrm{ml}$ respectively.

\section{Other laboratory investigations}

The serum concentration of total IgE was measured by ELISA using a commercial kit (Allergopharma, Reinbek, Germany) according to the manufacturer's instructions.

Table 1. Demographic and clinical characteristics of children with atopic dermatitis and healthy controls

\begin{tabular}{|c|c|c|c|}
\hline Parameter & $\begin{array}{l}\text { Atopic dermatitis } \\
\qquad n=\mathbf{5 7}\end{array}$ & $\begin{array}{l}\text { Healthy children } \\
\qquad n=34\end{array}$ & $p$ \\
\hline Age (years) & $7(4.0-11.2)$ & $8(5.0-14.0)$ & 0.3 \\
\hline Gender M/F & $34 / 23$ & $18 / 16$ & \\
\hline BMI $\left(\mathrm{kg} / \mathrm{m}^{2}\right)$ & $16.12(15.19-17.84)$ & $16.81(15.20-18.70)$ & 0.6 \\
\hline SCORAD & $32.5(26-45)$ & & \\
\hline $\operatorname{IgE}(\mathrm{IU} / \mathrm{ml})$ & $306.95(75.70-1022.80)$ & $28.00(18.00-47.00)$ & $<0.0001$ \\
\hline$\% \mathrm{E}$ & $5(3.2-8.7)$ & $1(0.0-2.0)$ & $<0.0001$ \\
\hline $\begin{array}{l}\text { Eosinophils absolute count } \\
(\text { cells/ } \mu \mathrm{l})\end{array}$ & $338(205-526)$ & $24.24(15.5-47.79)$ & $<0.0001$ \\
\hline
\end{tabular}

Data are presented as median and $25-75 \%$ interquartile range (IQR) 
Table 2. Serum levels of IL-1 $\beta$, IL-1 Ra and serum 25(OH) D concentration in examined children

\begin{tabular}{|c|c|c|c|}
\hline Parameter & $\begin{array}{l}\text { IL-1 } \beta \\
\mathrm{pg} / \mathrm{ml}\end{array}$ & $\begin{array}{l}\text { IL-1Ra } \\
\mathrm{pg} / \mathrm{ml}\end{array}$ & $\begin{array}{c}25(\mathrm{OH}) \mathrm{D} \\
\mathrm{ng} / \mathrm{ml}\end{array}$ \\
\hline \multicolumn{4}{|l|}{ Atopic dermatitis } \\
\hline All group, $n=57$ & $1.05(0.88-1.37)$ & $454.70(338.02-667.79)$ & $16.71(12.15-28.32)^{*}$ \\
\hline$<5$ years, $n=20$ & $1.01(0.82-1.46)$ & $682.60(434.32-1014.04) \#$ & $28.29(14.33-32.43)^{* *}$ \\
\hline$>5$ years, $n=37$ & $1.06(0.88-1.36)$ & $384.12(292.97-512.21)$ & $16.18(10.84-21.92)$ \\
\hline \multicolumn{4}{|l|}{ Healthy children } \\
\hline All group, $n=34$ & $0.98(0.74-1.40)$ & $430.90(259.04-561.15)$ & $22.55(19.51-28.60)$ \\
\hline$<5$ years, $n=11$ & $1.091(0.77-1.28)$ & $387.40(287.70-570.50)$ & $21.63(16.54-25.18)$ \\
\hline$<5$ years, $n=23$ & $0.91(0.58-1.45)$ & $443.91(299.28-526.09)$ & $22.74(19.89-28.52)$ \\
\hline
\end{tabular}

The blood eosinophil counts were determined using an automatic hematologic analyzer.

The statistical analyses were performed using MedCalc v. 13.1.2 software and data are presented as median and 25-75\% IQR. Kruskal-Wallis and Mann-Whitney U tests were used for comparisons between groups. Correlations between variables were tested using Spearman's test. $P$-values less than 0.05 were considered statistically significant.

\section{Results}

Children with AD had significantly higher both percentage and absolute count of eosinophils in peripheral

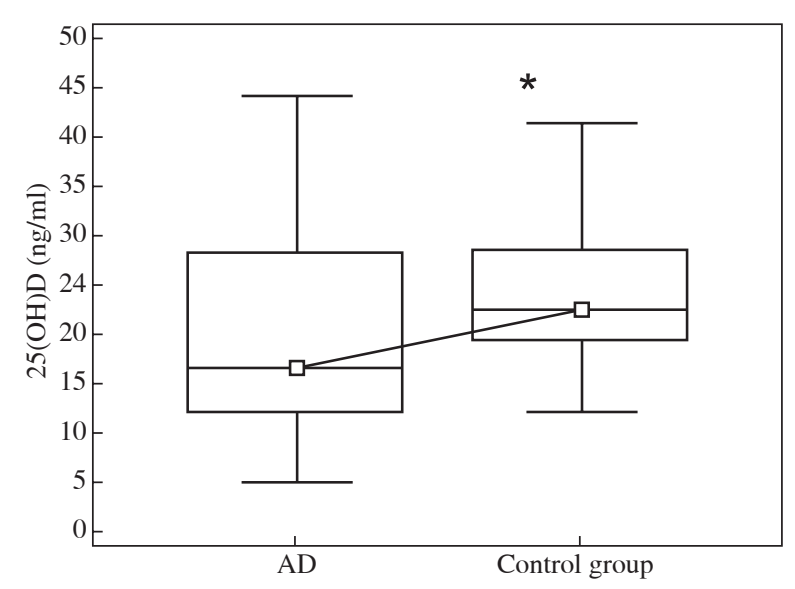

$p<0.0047$; Mann-Whitney $U$-test

$\square$ Median $\square 25-75 \%$ 工 Min-max

Fig. 1. Serum 25(OH)D in children with $A D$ and healthy children blood as well as serum IgE levels. The concentration of $25(\mathrm{OH}) \mathrm{D}$ in serum was significantly lower in children with AD than in healthy children (median 16.71, IQR 12.15$28.32 \mathrm{ng} / \mathrm{ml}$, median 22.55, IQR 19.51-28.60, respectively; $p<0.0047$ ) (Fig. 1). In the group of children with AD 29 children $(59.2 \%)$ had insufficiency, $12(24.5 \%)$ had deficiency and $8(16.3 \%)$ had a sufficient serum $25(\mathrm{OH}) \mathrm{D}$ level. In the control group 8 participants (26.5\%), 18 (52.9\%) and $7(20 \%)$ had insufficiency/deficiency/sufficiency of serum 25(OH)D levels, respectively. Children with AD and adequate serum vitamin D levels were significantly younger as compared to other groups (insufficiency/deficiency) (median 4, IQR 3.0-5.5, median 8, IQR 5.7-13.0, median 8, IQR 4.5-13.0 ng/ml, respectively; $p<0.02$ ) (Fig. 2A). Such differences were not detected in healthy children (Fig. 2B). No difference in SCORAD, serum IL-1 $\beta$, IL-1Ra level, IgE concentration, eosinophil percentage and absolute count between the 3 groups was found. There were higher median serum concentrations of L- $1 \beta$ and IL-1Ra in AD children as compared to healthy subjects, but these differences did not reach statistical significance (Table 2). The severity of $\mathrm{AD}$ was positively correlated with total IgE level, percentage and absolute count of eosinophils and IL-1Ra level $(r=0.44, p<0.007, r=0.38, p<003, r=0.49, p<0.0004$, $r=0.3, p<0.017$, respectively). In addition, IL-1 $\beta$ correlated with IL-1Ra $(r=0.26, p=0.05)$. No correlation between SCORAD and 25(OH)D levels was found $(r=-0.071$, $p<0.6)$. Neither total IgE nor eosinophils showed a significant association with serum $25(\mathrm{OH}) \mathrm{D}$ levels.

Additionally, in children below 5 years old with AD, 25(OH)D level was higher and IL-1Ra concentration was lower as compared with older children (Table 2). This relationship was not seen in healthy children. In children below age 5 a significant but weak correlation of SCORAD and IL-1Ra was found, similarly as in the whole group of children. 
A

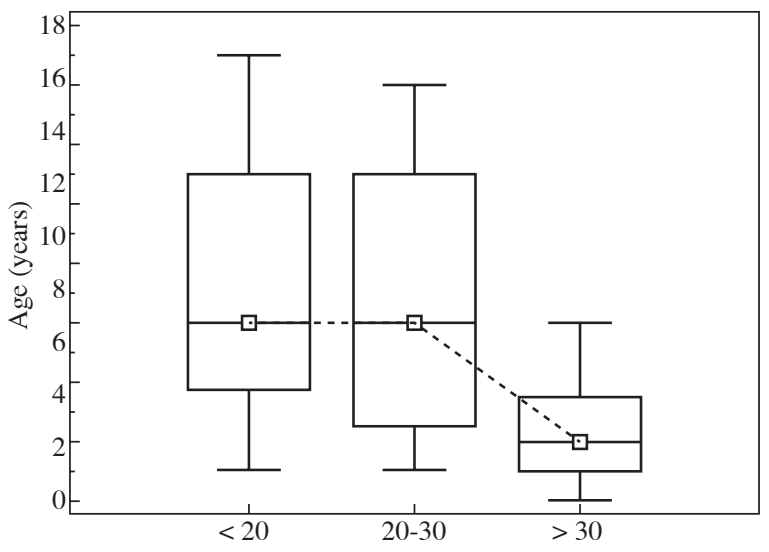

$p$-values from from Mann-Whitney $U$-test

$\square$ Median $\square 25-75 \%$ 工 Min-max

Fig. 2A. Comparison of age of AD children in relation to serum 25(OH)D level (insufficiency, deficiency, adequate level)

\section{Discussion}

Insufficiency and deficiency of vitamin D is one of the most prevalent health problems of the pediatric population in Poland. Our results showed that mean vitamin D level was significantly lower in children with AD compared to healthy subjects. Despite this, we did not find significant correlation between vitamin D status and AD severity, as measured by serum $25(\mathrm{OH}) \mathrm{D}$ concentration and SCORAD respectively. Although mean vitamin $\mathrm{D}$ level in the control group was significantly higher compared to the AD group, only in $20 \%$ of healthy children was the level adequate. In our study, vitamin D level was not correlated with serum IgE concentration and peripheral blood eosinophil percentage and absolute count, which remains in accordance with other studies $[18,19]$. The lack of correlation between serum vitamin D levels and SCORAD could be explained by the influence of other environmental factors on the course of the disease in the examined children. In our study vitamin D status in AD subjects was influenced by age. Children with sufficient serum vitamin D levels were younger than children with insufficiency/deficiency. To date, the evidence linking vitamin D to AD has been conflicting. Both increased and decreased vitamin D concentrations have been implicated as risk factors for the development of AD [20, 21]. Several researchers have found an inverse correlation between serum vitamin D levels and AD severity, particularly in patients with allergic sensitization [22-25], while in other studies the postulated causal association between vitamin $\mathrm{D}$ concentration and $\mathrm{AD}$ has been questioned $[18,26,27]$. In addition, the data
B

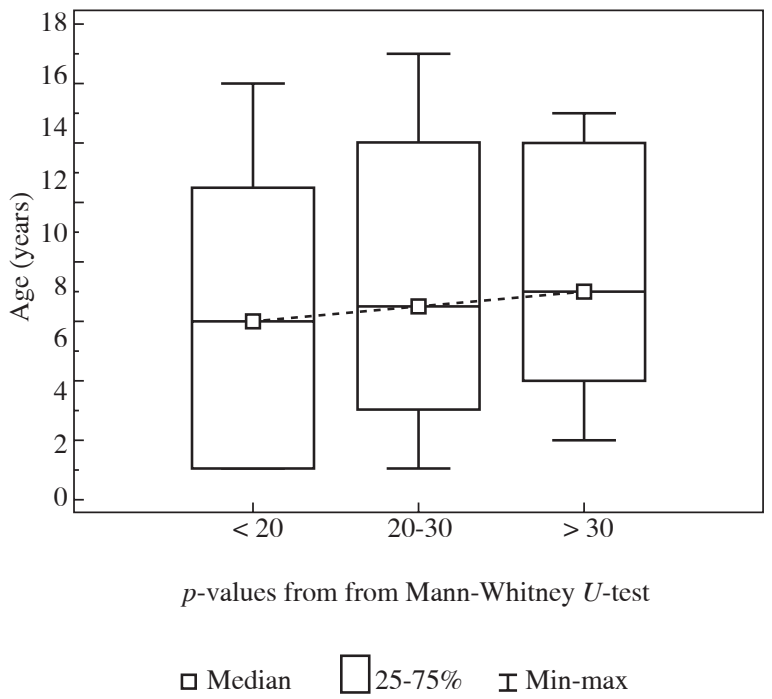

Fig. 2B. Comparison of age of healthy children in relation to serum 25(OH)D level (insufficiency, deficiency, adequate level)

from the literature documented that in individuals with $\mathrm{AD}$ lower vitamin D levels correlated with concentration of serum IgE directed to food and microbial antigens [23, 25]. Vitamin D formulas may also play a role in the treatment of AD. However, results from clinical studies evaluating the effect of vitamin D supplementation on patients with $\mathrm{AD}$ are inconsistent. Vitamin D supplementation may or may not alleviate symptoms of the disease [18, 28, 29], while vitamin $\mathrm{D}_{3}$ intake during pregnancy or infancy may or may not accelerate the development of $\mathrm{AD}[30,31]$.

The detailed mechanism of how vitamin D status may be connected with the development and course of AD remains unclear. Recent data suggest that vitamin D is an important modulator of the innate and adaptive immune response, both implicated in $\mathrm{AD}$ pathogenesis. In vitro vitamin $\mathrm{D}$ inhibits the surface expression of MCH II complex antigen and co-stimulatory molecules on antigen-presenting cells, downregulates Th1/Th17 subpopulation activity and promotes or has no influence on the Th2 activity and favors Treg cell development. [32]. Moreover, vitamin D increases human cathelicidin and antimicrobial peptide (LL-37) production in human keratinocytes and neutrophils, which in turn reduces skin colonization by Staphylococcus aureus strains [26].

Vitamin D modulates the inflammatory response by suppressing IL-1 family cytokine production and increasing IL-1Ra synthesis, which play crucial roles in regulation of both local and systemic inflammation [33]. According to the data from the literature low vitamin D levels could be associated with higher levels of the inflammatory IL-1 $\beta$ [34]. Similarly to other reports, in our study we estimated 
vitamin D at a single time point. A longitudinal or prospective cohort study with repeated measurements over time may have explained whether a constant association between $\mathrm{AD}$ and vitamin $\mathrm{D}$ deficiency exists.

Our study revealed a non-significantly higher concentration of IL-1 $\beta$ and IL-1Ra in children with $\mathrm{AD}$, and the levels subsequently increased with rising severity of AD. Moreover, a correlation between IL-1 $\beta$ and IL-1Ra was observed. The IL-1 receptor antagonist IL-1Ra, another member of the IL-1 family, competitively blocks the corresponding receptors, reducing the inflammatory response, but does not exert its own agonist activity. The balance between IL-1 and its receptor IL-1Ra plays an important role in modulation of the course of different diseases including diabetes, overweight, chronic rheumatoid diseases, sepsis, colitis, and granulomatous pulmonary disease $[4,7,8]$.

The potent biological effects of IL-1 $\beta$ are negatively regulated by secretory interleukin-1 receptor antagonist (sIL-1Ra). sIL-1Ra expression can be induced by pro-inflammatory stimuli such as IL-1 $\beta$ itself, viruses, bacteria, and microbial products, as well as a variety of immunomodulators such as GMCSF, IFN- $\beta$ and IFN- $\gamma$. The serum concentration of IL- $\beta$ is usually low, and in such cases IL-1Ra is measured as an indicator of the severity of various infections and non-infectious diseases [35].

Upregulated epidermal expression of IL-1 $\beta$ and IL-1Ra has been observed in adult patients with $\operatorname{AD}[36,37]$. In addition IL-Ra but not IL-1 $\beta$ correlated with some clinical parameters including severity of $\mathrm{AD}$ [36]. In one study performed in children with mild, moderate or severe AD, significant decreases in serum IL- $1 \beta$ levels after improvement of disease activity in all groups were observed [38].

Human keratinocytes express all of the essential inflammasome components and may activate and secrete IL-1 in response to allergen and microbial antigens [3842]. Ph-sensitive serine proteases (SPs) or kallikreins are activated after the $\mathrm{pH}$ skin increase observed in patients with AD and also activate IL-1 [43]. The release of IL-1 from the epidermis after activation is a primary event that promotes the induction of various cytokines, chemokines, and adhesion molecules and aggravates skin inflammation. On the other hand, downregulation of the inflammasome nucleotide-oligomerization binding domain receptor 3 (NLRP 3) in a Th2 milieu has been observed, which subsequently leads to an attenuated IL- $1 \beta$ response that might explain the increased susceptibility of patients with AD to infection caused by Staphylococcus aureus and herpes simplex virus [44].

\section{Conclusions}

In conclusion, in children with $\mathrm{AD}$ the serum vitamin D level was lower than in healthy children. The correlation between severity of AD and IL-1Ra may prove that inflammasome-dependent IL- $1 \beta$ is involved in immuno- pathogenesis of the disease. Further studies are needed on a larger population of children to confirm the role of this cytokine in development of AD.

\section{Acknowledgement}

This study was financially supported by Grant KNW$1-132 / / K / 5 / 0$ from the Medical University of Silesia in Katowice, Poland.

\section{The authors declare no conflict of interest.}

\section{References}

1. Kuo IH, Yoshida T, De Benedetto A, Beck LA (2013): The cutaneous innate immune response in patients with atopic dermatitis. J Allergy Clin Immunol 131: 266-278.

2. Boguniewicz M, Leung DY (2011): Atopic dermatitis: a disease of altered skin barrier and immune dysregulation. Immunol Rev 242: 233-246.

3. Schlapbach C, Simon D (2014): Update of skin allergy. Allergy 69:1571-1581

4. Abramovits W, Rivas Bejarano JJ, Valdecantos WC (2013): Role of interleukin 1 in atopic dermatitis. Dermatol Clin 31: 437-444.

5. Yamanaka K, Mizutani H (2015): "Inflammatory skin march": IL-1-mediated skin inflammation, atopic dermatitis, and psoriasis to cardiovascular events. J Allergy Clin Immunol 136: 823-824.

6. van de Veerdonk FL, Netea MG, Dinarello CA, Joosten LA (2011): Inflammasome activation and IL-1 $\beta$ and IL-18 processing during infection. Trends Immunol 32: 110-116.

7. Smith DE, Mason DR, Beck PL, Muruve DA (2012): Nucleotide-binding oligomerization domain-like receptors and inflammasomes in the pathogenesis of non-microbial inflammation anddiseases. J Innate Immun 4: 16-30.

8. Contassot E, Beer HD, French LE (2012): Interleukin-1, inflammasomes,autoinflammation and the skin. Swiss Med Wkly 142: w13590

9. Krause K, Metz M, Makris M, et al. (2012): The role of interleukin-1 in allergy-related disorders. Curr Opin Allergy Clin Immunol 12: 477-484.

10. Nambu A, Nakae S (2010): IL-1 and Allergy. Allergol Int 59: 125-135.

11. Machura E, Szczepańska M, Mazur B, et al. (2013): Interleukin 1- $\beta$, interleukin-1 receptor antagonist, and interleukin 18 in children with acute spontaneous urticaria. Biomed Res Int 2013: 605262.

12. Vestita M, Filoni A, Congedo M, et al. (2015): Vitamin D and atopic dermatitis in childhood. J Immunol Res 2015: 257879.

13. Oh JW. The clinical impact of vitamin D in children with atopic dermatitis (2013): Allergy Asthma Immunol Res 5: 179-180.

14. Benson AA, Toh JA, Vernon N, Jariwala SP (2012): The role of vitamin $\mathrm{D}$ in the immunopathogenesis of allergic skin diseases. Allergy 67: 296-301.

15. Mostafa WZ, Hegazy RA (2015): Vitamin D and the skin: Focus on a complex relationship: A review. J Adv Res 6: 793-804.

16. Hanifin JM, Rajka G (1980): Diagnostic features of atopic dermatitis. Acta Derm Venereol Suppl (Stockh) 92: 44-47. 
17. European Task Force on Atopic Dermatitis (1993): Severity scoring of atopic dermatitis: the SCORAD index. Dermatology 186: 23-31.

18. Samochocki Z, Bogaczewicz J, Jeziorkowska R, et al. (2013): Vitamin D effects in atopic dermatitis. J Am Acad Dermatol 69: 238-244.

19. Akan A, Azkur D, Ginis T, et al. (2013): Vitamin D level in children is correlated with severity of atopic dermatitis but only in patients with allergic sensitizations. Pediatr Dermatol 30: 359-363.

20. MesquitaKde C, Igreja AC, Costa IM (2013): Atopic dermatitis and vitamin D: facts and controversies. An Bras Dermatol 88: 945-953.

21. Palmer DJ (2015): Vitamin D and the Development of Atopic Eczema. J Clin Med 4: 1036-1050.

22. Wang SS, Hon KL, Kong AP, et al. (2014): Vitamin D deficiency is associated with diagnosis and severity of childhood atopic dermatitis. Pediatr Allergy Immunol 25: 30-35.

23. Peroni DG, Piacentini GL, Cametti E, et al. (2011): Correlation between serum 25-hydroxyvitamin D levels and severity of atopic dermatitis in children. Br J Dermatol 164: 10781082.

24. El Taieb MA, Fayed HM, Aly SS, Ibrahim AK (2013): Assessment of serum 25-hydroxy-vitamin D levels in children with atopic dermatitis: correlation with SCORAD index. Dermatitis 24: 296-301.

25. Baek JH, Shin YH, Chung IH, et al. (2014): The link between serum vitamin D level, sensitization to food allergens, and the severity of atopic dermatitis in infancy. J Pediatr 165: 849854.e1.

26. Kanda N, Hau CS, Tada Y, et al. (2012): Decreased serum LL-37 and vitamin D3 levels in atopic dermatitis: relationship between IL-31 and oncostatin M. Allergy 67: 804-812.

27. Chiu YE, Havens PL, Siegel DH, et al. (2013): Serum 25-hydroxyvitamin D concentration does not correlate with atopic dermatitis severity. J Am Acad Dermatol 69: 40-46.

28. Javanbakht MH, Keshavarz SA, Djalali M, et al. (2011): Randomized controlled trial using vitamins $\mathrm{E}$ and $\mathrm{D}$ supplementation in atopic dermatitis. J Dermatol Treat 22: 144-150.

29. Hata TR, Audish D, Kotol P, et al. (2014): A randomized controlled double-blind investigation of the effects of vitamin $\mathrm{D}$ dietary supplementation in subjects with atopic dermatitis. J Eur Acad Dermatol Venereol 28: 781-789.

30. Chawes BL, Břnnelykke K, Jensen PF, et al. (2014): Cord blood 25(OH)-vitamin D deficiency and childhood asthma, allergy and eczema: the COPSAC2000 birth cohort study. PLoS One 9: e99856.

31. Bäck O, Blomquist HK, Hernell O, Stenberg B (2009): Does vitamin $\mathrm{D}$ intake during infancy promote the development of atopic allergy? Acta Derm Venereol 89: 28-32.

32. Baeke F, Takiishi T, Korf H, et al. (2010): Vitamin D: modulator of the immune system. Curr Opin Pharmacol 10: 482496.

33. Kong J, Grando SA, Li YC (2006): Regulation of IL-1 family cytokines IL-1alpha, IL-1 receptor antagonist, and IL-18 by 1,25-dihydroxyvitamin D3 in primary keratinocytes. J Immunol 176: 3780-3787.

34. Grudet C, Malm J, Westrin A, Brundin L (2014): Suicidal patients are deficient in vitamin $\mathrm{D}$, associated with a pro-inflammatory status in the blood. Psychoneuroendocrinology 50: 210-219.

35. Arend WP (2002): The balance between IL-1 and IL-1Ra in disease. Cytokine Growth Factor Rev 13: 323-340.
36. Kezic S, O'Regan GM, Lutter R, et al. (2012): Filaggrin lossof-function mutations are associated with enhanced expression of IL-1 cytokines in the stratum corneum of patients with atopic dermatitis and in a murine model of filaggrin deficiency. J Allergy Clin Immunol 129: 1031-1039.e1

37. Abdel Hay RM, Ibrahim NF, Metwally D, Rashed LA (2013): The role of interleukin-1 $\beta$ and interleukin-33 in atopic dermatitis. Our Dermat Online 4: 11-14.

38. Nutan FN, Kanwar AJ, Parsad D (2012): The effect of topically applied corticosteroids on interleukin $1 \beta$ levels in patients with atopic dermatitis. J Eur Acad Dermatol Venereol 26: 1020-1022.

39. Kopfnagel V, Wittmann M, Werfel T (2011): Human keratinocytes express AIM2 and respond to dsDNA with IL-1 $\beta$ secretion. Exp Dermatol 20: 1027-1029.

40. Enk AH, Katz SI (1992): Early molecular events in the induction phase of contact sensitivity. Proc Natl Acad Sci U S A 89: 1398-1402.

41. Dombrowski Y, Peric M, Koglin S, et al. (2012): Honey bee (Apis mellifera) venom induces AIM2 inflammasome activation in human keratinocytes. Allergy 67: 1400-1407.

42. Boehm KD, Yun JK, Strohl KP, et al. (1996): In situ changes in the relative abundance of human epidermal cytokine messenger RNA levels following exposure to the poison ivy/oak contact allergen urushiol. Exp Dermatol 5: 150-160.

43. Thyssen JP, Kezic S (2014): Causes of epidermal filaggrin reduction and their role in the pathogenesis of atopic dermatitis. J Allergy Clin Immunol 134: 792-799.

44. Niebuhr M, Baumert K, Heratizadeh A, et al. (2014): Impaired NLRP3 inflammasome expression and function in atopic dermatitis due to Th2 milieu. Allergy 69: 1058-1067. 